\title{
Trends and Determinants of Raising ECBs in Indian Context
}

\author{
Ramakant Shukla \\ ramakantphd20@gmail.com
}

Abstract: This study examines the effect of capital control measures initiated during the last two decades in terms of all-in-cost ceilings and enhanced limits on ECB in India over the sample period 2004Q1 to 2020Q2. Using global liquidity, the exchange rate between INR/USD, imports and interest rate differentials as control variables and changes in capital control measures from 2008 to 2011 in the all-in-cost ceiling, and changes in the enhanced limits on ECBs from USD 500 million to USD 750 million under the automatic route in 2012, regression analysis of three ECB series show interesting results. Using Robust Least Squares method, we document that (1) the successive increment in all-in-cost ceilings on ECB from 2008 to 2011 is inducing ECBs to flow, indicating that Indian firms benefit more than they pay due to increase the cost for ECBs having maturities $3<5$ years. However, such capital control measures are not effective on ECBs having maturities $>5$ years. (2) The effect of the enhanced limits on ECBs from USD 500 million to USD 750 million under the automatic route in 2012 has a pronounced impact on ECB, averaging 1602.1 USD million per quarter. We observed that CCAs in India are initiated in response to the volatility of the exchange rate and global liquidity, imports, and interest rate differentials are significant variables in India's required capital control actions.

Keywords: External Commercial Borrowing; Exchange Rate Volatility; Global Liquidity; Regulation of External Commercial Borrowing, Robust Least Squares, India

\section{Introduction}

When domestic liquidity is not enough to meet the demand of borrowing, and the exchange rates also depreciate between INR/USD, Indian regulators have to release the grip on capital controls (EPW, 1995). India initiated capital controls in the country for the first time in the Second World War and kept increasing it in subsequent decades. However, Capital controls on foreign debt had to be liberalized in the early 1990s when India faced the BoPs crisis. India introduced the Liberalization, Privatization, and Globalization (LPG) model as an economic reform in 1991 and followed an open door policy. This policy became the reason for opening up the door of private capital flows in India, but this was only allowed to continue under regulatory restrictions on debt creating flows (Patnaik, Shah, \& Singh, 2015).

External commercial borrowings (ECB) has emerged as an essential item of the capital account in India's Balance of Payments (BoP) and is a crucial channel to facilitate access to foreign capital by Indian corporates and public sector units (PSUs)" (Patnaik, Shah, \& Singh, 2014). This vehicle of funds raising in the international capital markets are regulated by the Reserve Bank of India (RBI) in consultation with the Ministry of Finance, Government of India. The whole statutory laws governing ECBs are contained in the Foreign Exchange Management Act (FEMA), 1999. Since ECBs can be obtained through two routes; in both cases, "numerous restrictions are governing who can borrow, who can lend, the terms of the borrowing (amount and tenor), the uses to which the borrowed amount can be put ('end-use restrictions'), and the maximal interest rate that can be paid ('all-in-cost restrictions'). The maze of rules introduces many unintentional consequences" (Patnaik et al., 2014).

This study examines the effect of capital control measures initiated during the last two decades in terms of all-in-cost ceilings and enhanced limits on ECB. We have used volatility of returns on the USD/INR exchange rate, global liquidity, import, and interest rate differentials as control variables and two dummy variables to account for capital control actions. The first dummy variable accounts for changes introduced in all-in-cost ceilings on ECB from 2008 to 2011 , and the second dummy variable is used to account for the change introduced on enhanced limits on ECB in 2012. No study has been conducted with such objective in India except Pandey, Pasricha, Patnaik, and Shah (2019). They examined the effectiveness of CCAs using a coding method where 0 represented loosing of a policy rule and 1 represented tightening of a policy rule; however, our study is focused on only two types of CCAs.

The rest of the study is arranged as follows: A brief discussion of the theoretical and empirical literature is presented in Section II with research gap. Section III contains graphical presentations of historical trends of ECBs and control variables. Section IV contains objectives or motivation of the study. Research methodology and empirical results are discussed in Section V and Section VI respectively, and Section VII concludes. 


\section{Review of Literature and Research Gap}

During the first three decades after India's independence, business corporations had limited borrowing from the international capital market. However, when India refused to take recourse to foreign assistance from debt, External commercial borrowing became the most important instrument to meet the need for funds in the 1980s. It continued in India until the balance of payment crisis in the early 1990s. The main reason for the historically low ECB levels of ECBs in India during the 1990s was that international investors had lost confidence because of India's downgraded sovereign risk ratings (Sur, Ray, \& Nandy, 2019).

However, India was able to tide away from the Balance of Payment crisis with the LPG policy and adopted the most suitable external debt managing policy. Although India adopted a calibrated approach in its capital account management, it moved to a floating exchange rate system from a pegged exchange rate, ultimately leading to the current account convertibility in 1994. Significant reforms were also introduced in India's external sector since the early 1990s. External financing, including debt flows, has generally financed India's current account deficit (Mohan \& Kapur, 2009).

When India adopted the LPG policy to overcome the balance of payment crisis in the early 1990s, a shift in India's funds flows was noticed. After the 1990s, private external borrowings exceeded the government's official external borrowings (Gopinath, 2004). During this period, ECB became the most preferred medium to borrow funds from the international market.

Kapoor (2015), using time series analysis, explored which of the factors such as exchange rate, interest rate differential, and real domestic activity drives the Indian firms to acquire funds from the international financial markets and reported that real domestic activity has a positive association with raising funds in the international financial market. Further, it was observed that an appreciation in the exchange rate between INR/USD increases external commercial borrowings.

A. Acharya, Salvi, and Kumar (2017) investigated the relative importance of global liquidity as a determinant of India's external financial flows among a set of other global factors. They documented that global liquidity movements affect India's foreign investment flows more than foreign direct investment and external commercial borrowings.

Tripathy (2019) studied the trends and policies of ECB flows in India taking data on various economic variables for the pre and post global financial crisis period. He concluded that the policy towards ECBs is being gradually relaxed in order to facilitate Indian corporations; especially, to make funds available for the infrastructure development in India. Arora, Rathinam, and Khan (2010) analysis showed that the negative effect of the global financial crisis coming through foreign capital flows was neutralized having effective monetary and fiscal policy capital account liberalization. Arunperumal (2016) investigated the relationship between external commercial borrowings and exchange rates, interest rate differentials, and real domestic activity and found that external commercial borrowings' flow is influenced by exchange rates, interest rate differentials, and real domestic activity. Dev (2017) reported a long-run positive relationship of ECB with Index of industrial production, Interest rate differential, Exchange rate, and a negative association with foreign investment and imports. Pandey et al. (2019) revealed that "capital controls are tightened after appreciation and eased after depreciation of the exchange rate. The results suggested no impact of capital controls on most variables, including the currency." They investigated the reasons for changing capital controls and their effectiveness in India. To assess the impact of controls, they employed both event study and propensity score matching methodologies. Event study methodology showed no impact of capital controls on most variables evaluated, but reveals limited evidence that capital controls relieve currency pressures in the short term. However, even this limited evidence disappeared once selection bias was controlled for.

Literature on Capital Control Actions on external funds raising by business corporations is scant. However, it is shown that no study has been conducted with such objective in India except Pandey et al. (2019). They examined the effectiveness of CCAs using a coding method where 0 represented loosing of a policy rule and 1 represented tightening of a policy rule. Our study differs from their study because we are focusing on only two types of CCAs, whereas they considered all CCAs taken until 2015 in India.

\section{Trend Analysis of Variables}

This section plots the variables used in this study to show a general trend over the sample period. First, all the three External Commercial Borrowings (ECB) series are plotted in Figure 1, and Figure 2 plots other four control variables.

\subsection{Three ECB Series}

Figure 1 show values of three ECB series employed as dependent variables in this study for the period 2004M1 to 2020M6. First part of Figure 1 presents values of ECB with maturities $3<5$ years. 


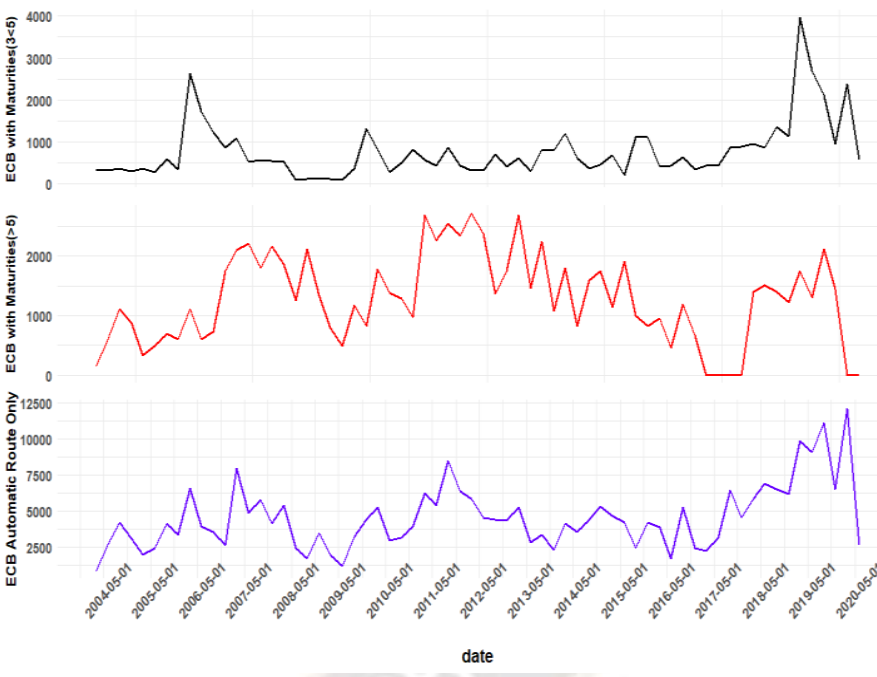

Figure 1 Values of ECB New Deals

Source: Compiled from monthly data obtained from https://rbi.org.in/Scripts/ECBView.aspx

The general trend in this ECB series is flat except for 2005 and 2017 when it became the highest. The second part of Figure 1 shows values of ECB with maturities $>5$ years. This ECB series shows mush variations, and it also became zero in 2017 and 2020. Finally, the last part of Figure 1 shows values of ECB procured through automatic route only. This series does not show much variation, but an uptrend is noticed in this series from 2017.

\subsection{Trends in Exchange Rate, Global Liquidity,} Imports, and Interest Rate Differentials

To calculate exchange rate volatility, we used the standard deviation of exchange rate following Arize (1997) and Pozo (1992).

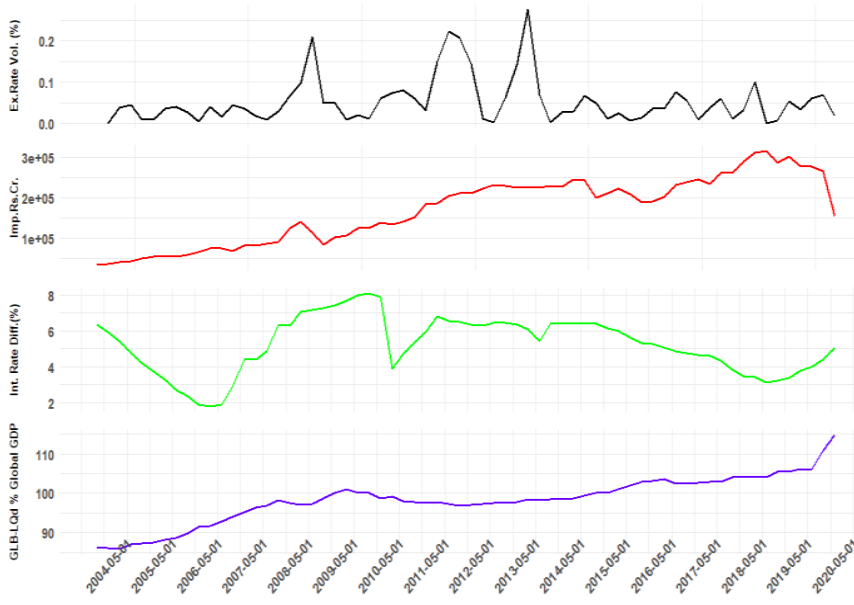

date

Figure 2 Global Liquidity, exchange rate volatility, Imports, and Interest Rate Differentials Trends

Compiled from monthly data obtained from:

https://dbie.rbi.org.in/DBIE/dbie.rbi?site=statistics\#!48 (Imports \& exchange rate); Global liquidity:

https://stats.bis.org/statx/srs/table/e1?p=20094\&c=\# and PLR: https://tradingeconomics.com/india/indicators ; LIBOR:

https://fred.stlouisfed.org/; (Interest rate differentials)

That is, each point in Figure 2 is the daily volatility of returns on the USD/INR exchange rate, computed over a centered window of width 63 trading days. A doubling of exchange rate volatility took place on 13 July 2013 in the third period, which lasted for more than two years.

After 2014, until the end of Q2 of 2020, the daily volatility of returns on the USD/INR exchange rate remained below 0.4 percent with a few exceptions. Figure 2 also plots three additional control variables besides exchange rate volatility: global liquidity, imports, and interest rate differentials. Imports and Global liquidity show an uptrend during the sample period. The average value of interest rate differentials (IRD) is 5.20 during the high enough period to encourage Indian firms to borrow in the international market and reduce their cost of borrowings.

\section{Objectives}

This study has been conducted to achieve the following objective:

To measure the impact of Capital Control Actions (CCA) on external commercial borrowings (ECB) in India

\subsection{Hypotheses of the Study}

Since this study is utilizing three ECB series which either differ in maturities or routes, the following three hypotheses are formulated so that rejection or non-rejection of each of the alternative hypotheses can be done separately.

$\mathrm{H}_{1}$ : Changes introduced in all-in-cost ceilings on ECB from 2008 to 2011 has a positive and significant impact on ECBs with maturities $3<5$ years.

$\mathrm{H}_{2}$ : Changes introduced in all-in-cost ceilings on ECB from 2008 to 2011 has a positive and significant impact on ECBs with maturities $>5$ years.

$\mathrm{H}_{3}$ : The effect of the enhanced limits on ECBs (Automatic route only) from USD 500 million to USD 750 million under the automatic route in 2012 has a positive and significant impact.

\section{Methodology and Data}

After establishing a long-run relationship between five country-specific factors (Pull factors) and three global factors (Push factors) with ECB out of ten pull factors and five push factors, the Variance Decomposition Method (VDM) was employed to understand that which of them cause most variation in ECB in India. All the pull and push factors were selected based on literature review. A total of 159 research articles were collected from 1984 to 2020, out of which 91 research articles were related to external funds flow in one or more aspects; however, only 35 studies were found in which factors affecting external commercial borrowings were discussed. These studies include: Hausmann and Panizza (2003)/ 91 Countries; Sekhar 
(2006)/ India; Singh (2007)/ India; Narayan (2008)/ India; Ghosh (2008)/ India; Singh (2009)/ India; Verma and Prakash (2011)/ India; Mora, Neaime, and Aintablian (2013) /Lebanon; Kumarasamy (2012)/ India; Pacheco (2012) / India; DEOKAR and JANGILI (2013) / India; Meisami, Misra, Mehran, and Shi (2014) / India; (Gaiha, Padhi, \& Ramanathan, 2014) / India; Patnaik et al. (2014) / India; Kapoor (2015) / India; Acharya et al. (2015) / India; Shukla (2016) / India; Pal (2016) / India; Acharya and Vij (2016) / India; Arunperumal (2016) / India; Bose, Mallick, and Tsoukas (2017) / India; Dev (2017) / India; SRIVASTVA and RAMAN (2017)/ India; Ray (2017) / India; Venkatesan (2018)_ / India; Sinha and Agnihotri (2018) / India; Bougheas, Lim, Mateut, Mizen, and Yalcin (2018) / South Korea; Pradhan and Hiremath (2019) / India; BrafuInsaidoo, Ahiakpor, Vera Ogeh, William G, and McMillan (2019) / Ghana; Sur et al. (2019) / India; Misra and Shettigar (2020) / India. We identified fifteen drivers under pull and push factors from these studies. Pull factors include Country Risk, Domestic Financial Sector Development, Exports, Imports, GDP, and Restrictions on Overseas Borrowings, Exchange Rate, Inflation, Domestic Liquidity, and Openness of the Economy and Push factors include Global Liquidity, Global Risk Aversion, US-Inflation, Interest Rate Differential, and the Strength of US Output Growth. This study has identified ten pull factors and five push factors. After determining the stationarity of these variables, eight of them were used in the ARDL cointegration test with ECBs followed by ECM models and Variance Decomposition methods.

Results revealed that exchange rate, global liquidity, imports, and interest rate differentials caused most ECB variation to reach $20.23 \%, 12.38 \%, 11.51 \%$, and $14.80 \%$ in a window of ten quarters, respectively, as indicated in Table 1. These variables are included in the model to control their effect while measuring the effect of CCAs on ECBs.

Table 1.Variance Decomposition of ECB

\begin{tabular}{|c|c|c|c|c|c|c|c|c|c|c|}
\hline & S.E. & ECB & D(EXC) & D(GLBL_E1) & D(IMPO) & D(IND_INF) & D(IRD) & D(OPN_EC) & D(US_GDP) & D(EXPORT) \\
\hline 1 & 2163.632 & 100.0000 & 0.000000 & 0.000000 & 0.000000 & 0.000000 & 0.000000 & 0.000000 & 0.000000 & 0.000000 \\
\hline 2 & 4017.504 & 60.67319 & 22.61443 & 1.992384 & 0.773356 & 5.410089 & 5.366100 & 0.740993 & 1.273147 & 1.156319 \\
\hline 3 & 4656.795 & 46.20479 & 35.47785 & 1.551330 & 2.083732 & 4.508799 & 6.121812 & 1.087031 & 1.094795 & 1.869868 \\
\hline 5 & 6800.280 & 46.55151 & 17.99630 & 6.415778 & 8.322964 & 3.436075 & 7.162112 & 4.587243 & 0.845512 & 4.682504 \\
\hline 6 & 7474.857 & 40.90914 & 16.80361 & 5.488100 & 12.44112 & 2.843943 & 5.947435 & 4.393856 & 3.520024 & 7.652773 \\
\hline 7 & 8468.559 & 32.29265 & 13.53584 & 13.32217 & 16.07186 & 3.801643 & 6.803234 & 3.619324 & 2.744747 & 7.808525 \\
\hline 8 & 8696.399 & 30.95507 & 13.23913 & 12.77674 & 15.39355 & 7.039185 & 6.468432 & 3.944182 & 2.756144 & 7.427578 \\
\hline 9 & 10047.30 & 24.43286 & 15.68590 & 13.08944 & 13.84929 & 5.273574 & 11.98104 & 3.987208 & 5.048675 & 6.652029 \\
\hline 10 & 11061.55 & 21.08160 & 20.23174 & 12.38472 & 11.51307 & 6.171968 & 14.80506 & 3.300360 & 4.876069 & 5.635413 \\
\hline
\end{tabular}

Hence, we have formulated the following regression model:

maturities $3<5$ years; the second series contains observations with maturities more than 5 years, and the third series has ECB of all maturities procured through automatic route only. $\varepsilon_{\mathrm{i}}$ is white noise error correction term.

Dummy $_{\mathrm{CC}}$ is used to account for changes in capital control Where,

$$
\begin{array}{r}
E C B_{t}=\alpha+\beta_{E X} E X_{\sigma t}+\beta_{G L} G L_{t}+\beta_{I M P} I M P_{t} \\
+\beta_{I R} I R_{t}+\beta_{D} D^{2} \text { mmy } \\
C C
\end{array}
$$

$\mathrm{ECB}_{\mathrm{t}}$ is the amount of External Commercial borrowings in USD Millions, EX represents exchange rate differential,

G.L. is a Global liquidity measure as a percentage of global GDP,

IMP is the value of imports in Crores of Rupees, and I.R. represents Interest rate differential.

To calculate exchange rate volatility (EX), we used the standard deviation of the exchange rate following Arize (1997) and Pozo (1992). Global liquidity (G.L.) variable is obtained from BIS. Interest rate differentials (I.R.) are calculated using the mostly employed method: Prime Lending Rate - (LIBOR+350 bps).

There are three ECB series in this study used as dependent variables. The first series contains observations only having measures in India. Dummy(1) is used for all-in-cost ceiling increments. One is given for 150; two for 200; three for 300 , and four for 350 for $\geq$ three years $\leq$ five years, and the same is for maturity more than five years. The sample period of the study is 2004Q1-2020Q2.

Table 2 below presents all-in-cost ceilings over six months LIBOR based on U.S. Dollar (Basis points), the interest rate paid for ECB by an Indian firm. These limits are the maximal interest rates spelled out according to maturity and are changed from time to time by RBI following the objectives of currency policy.

\begin{tabular}{|c|c|c|c|}
\hline Date of RBI circulars & $\geq$ Three years $\leq$ five years & $\geq$ Five years $\leq$ seven years & $\geq$ Seven years \\
\hline 31.01 .2004 & 200 & 350 & 350 \\
\hline 21.05 .2007 & 150 & 250 & 250 \\
\hline 29.05 .2008 & 200 & 350 & 350 \\
\hline
\end{tabular}

Table 2 All-in-cost ceilings over six months LIBOR based on USD (Basis points) 
International Journal on Recent and Innovation Trends in Computing and Communication

ISSN: 2321-8169 Volume: 9 Issue: 7

DOI: https://doi.org/10.17762/ijritcc.v9i7.5475

Article Received: 26 June 2021 Revised: 02 July 2021 Accepted: 10 July 2021 Publication: 31 July 2021

\begin{tabular}{|l|r|r|r|}
\hline $\mathbf{2 2 . 0 9 . 2 0 0 8}$ & 200 & 350 & 450 \\
\hline $\mathbf{2 2 . 1 0 . 2 0 0 8}$ & 300 & 500 & 500 \\
\hline 09.12 .2009 & 300 & 500 & 500 \\
\hline 23.11 .2011 & 350 & 500 & 500 \\
\hline
\end{tabular}

Source: https://www.finmin.nic.in/sites/default/files/SahooCommittee_ecbReport_20150225.pdf

Since the RBI enhanced the limit on ECBs from USD 500 million to USD 750 million under the automatic route in $2012,{ }^{1}$ this policy change on enhanced borrowings limits DUMMY (2) is utilized, having a value of 0 in all quarters before 2012 and 1 otherwise. ADF unit root test revealed that all the control variables were not stationary at level but became stationary after first differencing. Still, all the three ECB series were stationary at level.

Table 3 ADF Unit Root Test

\begin{tabular}{|c|c|c|c|c|c|c|c|c|c|}
\hline Variables & With Constant & & 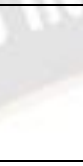 & $\begin{array}{l}\text { With } \\
\text { Constant \& } \\
\text { Trend } \\
\end{array}$ & & 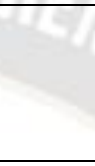 & $\begin{array}{l}\text { Without Constant } \\
\text { \& Trend }\end{array}$ & & \\
\hline & t-Statistic & Prob. & & $\mathrm{t}$-Statistic & Prob. & & $\mathrm{t}$-Statistic & Prob. & \\
\hline AUT_ECB & -2.9824 & 0.0434 & $* *$ & -2.7442 & 0.2237 & no & -0.6429 & 0.4343 & n0 \\
\hline $\mathrm{ECB}(3<5)$ & -4.4634 & 0.0006 & $* * *$ & -4.7563 & 0.0014 & $* * *$ & -1.6441 & 0.0942 & $*$ \\
\hline $\mathrm{ECB}(>5)$ & -2.9394 & 0.0413 & $* *$ & -2.5036 & 0.3254 & n0 & -0.7273 & 0.3971 & n0 \\
\hline IRD & -1.8219 & 0.3669 & n0 & -1.7992 & 0.6938 & n0 & -0.742 & 0.3912 & n0 \\
\hline IMPORTS & -1.6981 & 0.4275 & no & -0.415 & 0.985 & no & -0.0764 & 0.6535 & n0 \\
\hline GLBL_LQD & 0.2976 & 0.9765 & no & -1.0776 & 0.9246 & n0 & 2.3287 & 0.9949 & n0 \\
\hline EXC & 0.5413 & 0.9869 & n0 & -2.6498 & 0.2606 & n0 & 2.2444 & 0.9937 & n0 \\
\hline & & & & $y$ & & $+\infty$ & & & \\
\hline$\underbrace{\text { First Diff. }}_{\text {Variables }}$ & With Constant & & & $\begin{array}{l}\text { With } \\
\text { Constant \& } \\
\text { Trend }\end{array}$ & & & $\begin{array}{l}\text { Without Constant } \\
\& \text { Trend }\end{array}$ & 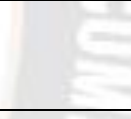 & \\
\hline & $\mathrm{t}$-Statistic & Prob. & & $\mathrm{t}$-Statistic & Prob. & 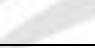 & $\mathrm{t}$-Statistic & Prob. & \\
\hline d(AUT_ECB) & -12.361 & 0 & $* * *$ & -12.2716 & 0 & $* * *$ & -12.4718 & 0 & $* * *$ \\
\hline $\mathrm{d}(\mathrm{ECB}(3<5))$ & -4.8069 & 0.0002 & $* * *$ & -4.738 & 0.0016 & $* * *$ & -4.7907 & 0 & $* * *$ \\
\hline $\mathrm{d}(\mathrm{ECB}(>5))$ & -12.7958 & 0 & $* * *$ & -12.7552 & 0 & $* * *$ & -12.9128 & 0 & $* * *$ \\
\hline $\mathrm{d}(\mathrm{IRD})$ & -6.8021 & 0 & $* * *$ & -6.7509 & 0 & $* * *$ & -6.8576 & 0 & $* * *$ \\
\hline d(IMPORTS) & -4.8924 & 0.0001 & $* * *$ & -5.0623 & 0.0005 & $* * *$ & -4.9448 & 0 & $* * *$ \\
\hline d(GLBL_LQD) & -4.4564 & 0.0006 & $* * *$ & -4.4623 & 0.0036 & $* * *$ & -3.7206 & 0.0003 & $* * *$ \\
\hline $\mathrm{d}(\mathrm{EXC})$ & -6.0282 & 0 & $* * *$ & -6.1377 & 0 & $* * *$ & -5.6944 & 0 & $* * *$ \\
\hline
\end{tabular}

a: $(*)$ Significant at the $10 \% ;(* *)$ Significant at the 5\%; (***) Significant at the $1 \%$ and (no) Not Significant;

b: Lag Length based on SIC; c: Probability based on MacKinnon (1996) one-sided p-values.

${ }^{1}$ A.P. (DIR Series) Circular No. 25 dated 23 September 2011 


\section{Analysis and Findings}

When OLS regression was used, a positive autocorrelation was noticed in error terms in all models, and other assumptions of OLS were also violated in some models. A positive autocorrelation can be detected through the D-W test statistic value whenever it is less than 2.0, which is the most common case in time series data analysis. Hence, robust least squares were used as a solution. This technique is designed to be less sensitive to outliers.

In all the six models presented in Table 4 below, the coefficients are BLUE, and the residuals of the models are NIID $(0, \sigma)$. It is achieved through using the Robust Least Squares method. Hence, assumptions of OLS regression will not be discussed hereafter. We have calibrated regression models with and without dummy variables representing capital control measures to notice the change in control variables and R-squared values between them. Thus, we have calibrated six models having 3 ECB series.

Model 1 is calibrated without using the dummy variable representing changes in capital control measures. The dependent variable is ECB with maturities $3<5$ years. Rsquared is $1.57 \%$, and only two independent variables, imports and global liquidity are statistically significant at $10 \%$ and $1 \%$ significance level and carry the expected signs.

The second model is calibrated using the variable of interest, which is the dummy variable representing change in capital control measures. The dependent variable is ECB with maturities $3<5$ years. The dummy variable representing capital control measures is significant at a $5 \%$ significance level and is positive. Hence, $\mathrm{H}_{1}$ is not rejected. R-squared of this model has increased to approx. $8 \%$ from $1.6 \%$, indicating that this capital control loosening is meaningful and bringing-up the desired results because it increases ECB procurement by 128.72 USD million per quarter if a 50 basis point is increased. Imports and global liquidity are again significant, but imports have risen from $10 \%$ to $1 \%$.

Models 3 and 4 are calibrated, having ECBs of maturities $>5$ as a dependent variable and the four control variables. Model 3 does not contain a dummy for capital control measures. In this model, exchange rate and interest rate differentials are significant at 5\%, and $1 \%$ significance level, respectively and are positive. Model 4 also includes a dummy for capital control measures besides the other four control variables as included in model 3. Still, the dummy representing capital control measures is not statistically significant, which indicates that Indian firms do not prefer the loosening of capital control measures in terms of availing more costly loans in international markets for ECBs having maturities more significant than five years. Hence, $\mathrm{H}_{2}$ is rejected.

Models 5 and 6 are calibrated, having ECBs of all maturities procured through an automatic route. Control variables are the same as in previous models. Model 5 does not include the dummy for capital control measures and shows that only interest rate differential is significant at a $5 \%$ significance level. However, model 6 with dummy variable included shows that dummy for capital control measures is significant at $5 \%$ significance level besides interest rate differential which is significant at $1 \%$ significance level indicating that the level of significance of interest rate differential has increased from 5\% in Model 5 to $1 \%$ in Model 6. Results of model 6 also show that the R-squared value has increased from $9.18 \%$ to $16.15 \%$, indicating that Model 6 with dummy variable included accounts for more ECB variation than Model 5. Hence, $\mathrm{H}_{3}$ is not rejected.

\section{Table 4 Robust Least Squares}

\begin{tabular}{|c|c|c|c|c|c|c|}
\hline Variable & ECB3<5 & ECB3<5 & $E C B>5$ & $\mathrm{ECB}>5$ & $\begin{array}{c}\begin{array}{c}\text { ECB } \\
\text { (All } \\
\text { Maturities)* }\end{array} \\
\end{array}$ & $\begin{array}{c}\text { ECB } \\
\text { (All } \\
\text { Maturities)* }\end{array}$ \\
\hline & Model 1 & Model 2 & Model 3 & Model 4 & Model 5 & Model 6 \\
\hline \multirow[t]{2}{*}{$\mathrm{D}(\mathrm{EXC})$} & 2.82275 & -15.7218 & $101.07 * *$ & $106.4378^{* *}$ & 198.0144 & 127.119 \\
\hline & $(0.090448)$ & $(-0.52447)$ & $(2.18854)$ & $(2.38380)$ & (1.03832) & (0.69909) \\
\hline \multirow[t]{2}{*}{ D(IMPORTS) } & $0.005664 *$ & $0.0072 * * *$ & 0.000178 & 0.002343 & 0.010821 & 0.020086 \\
\hline & (1.735196) & (2.330075) & $(0.02917)$ & $(0.39933)$ & $(0.54251)$ & (1.05488) \\
\hline \multirow[t]{2}{*}{$\mathrm{D}(\mathrm{IRD})$} & 28.26489 & 51.08416 & $502.43 * * *$ & $812.316^{* * * *}$ & $1176.61 * *$ & $1427 * * *$ \\
\hline & $(0.35831)$ & (0.691595) & (4.45190) & (7.68510) & $(2.44092)$ & (3.13138) \\
\hline D(GLBL_LQD) & $217.7049 * * *$ & $264.20 * * *$ & 43.64231 & 20.39656 & -358.1262 & 216.6179 \\
\hline
\end{tabular}


DUMMY

-
$517.769 * * *$
$(7.986501)$
$\mathbf{0 . 0 1 5 7 4 2}$
M settings: weight=Bisquare, tum
tics in parentheses. $*$ indicates EC
hat the effect of the enhanced
00 million to USD 750 million
2012 has a pronounced impact
1 USD million per quarter.
visible in Figure 2 of this text.

\section{Summary and Conclusions}

This study aimed to examine the effect of capital control measures initiated during the last two decades in terms of all-in-cost ceilings and enhanced ECB limits. We used volatility of returns on the USD/INR exchange rate, global liquidity, imports, and interest rate differentials as control variables and two dummy variables to account for capital control actions. The first dummy variable accounts for changes introduced in all-in-cost ceilings on ECB from 2008 to 2011 , and the second dummy variable is used to account for the change introduced on enhanced limits on ECB in 2012. The sample period was 2004Q1-2020Q2. Using Robust Least Squares method, we document that (1) the successive increment in all-in-cost ceilings on ECB from 2008 to 2011 is inducing ECBs to flow, indicating that Indian firms benefit more than they pay due to increase the cost for ECBs having maturities $3<5$ years. However, such capital control measures are not effective on ECBs having maturities $>5$ years. (2) The effect of the enhanced limits on ECBs from USD 500 million to USD 750 million under the automatic route in 2012 has a pronounced impact on ECB, averaging 1602.1 USD million per quarter.

This study results reveal two things about the CCAs in India. Firstly, CCAs in India are initiated in response to the volatility of the exchange rate. Secondly, global liquidity, imports, and interest rate differentials are significant variables in India's required capital control actions. Hence, we find evidence that Indian authorities should consider these four variables while formulating ECB policies.

\section{References}

[1]. Acharya, Cecchetti, S. G., De Gregorio, J., KalemliÖzcan, Ş., Lane, P. R., \& Panizza, U. (2015). Corporate debt in emerging economies: A threat to financial stability?
[2]. Acharya, \& Vij, S. (2016). Foreign currency borrowing of corporations as carry trades: Evidence from india. Paper presented at the NSE-NYU Conference on Indian Financial Markets.

[3]. Acharya, A., Salvi, P., \& Kumar, S. (2017). Global Liquidity and Foreign Portfolio Flows to India: An Empirical Assessment. Financial Times.

[4]. Arize, A. C. (1997). Conditional exchange-rate volatility and the volume of foreign trade: Evidence from seven industrialized countries. Southern Economic Journal, 235-254.

[5]. Arora, D., Rathinam, F. X., \& Khan, M. S. (2010). India's experience during current global crisis: A capital account perspective. Public Policy Review, 6(5), 807-836.

[6]. Arunperumal, A. (2016). External commercial borrowings in India-An Overview. International Journal on Recent and Innovation Trends in Computing and Communication, 4(11), 208-213.

[7]. Bose, U., Mallick, S., \& Tsoukas, S. (2017). Does Easing Controls on External Commercial Borrowings boost Exporting Intensity of Indian Firms? Paper presented at the Conference paper.

[8]. Bougheas, S., Lim, H., Mateut, S., Mizen, P., \& Yalcin, C. (2018). Foreign currency borrowing, exports and firm performance: evidence from a currency crisis. The European Journal of Finance, 24(17), 1649-1671.

[9]. Brafu-Insaidoo, W. G., Ahiakpor, F., Vera Ogeh, F., William G, C., \& McMillan, D. (2019). Macrodeterminants of short-term foreign debt in Ghana. Cogent Economics \& Finance, 7(1). doi:10.1080/23322039.2019.1630161

[10]. DEOKAR, B. K., \& JANGILI, R. (2013). Bank and External Borrowings of the Corporate Sector. Economic and Political Weekly, 133-135.

[11]. Dev, S. (2017). External commercial borrowings in India and its sensitivity to macroeconomic factors: An empirical analysis. Available at SSRN 2406766.

[12]. EPW. (1995). Looking for Palliatives. Economic and Political Weekly, 30(47).

[13]. Gaiha, A., Padhi, P., \& Ramanathan, A. (2014). An empirical investigation of causality from capital flows to exchange rate in India. International Journal of Social Sciences and Entrepreneurship, 1(10), 59-69.

[14]. Ghosh, S. (2008). Leverage, foreign borrowing and corporate performance: firm-level evidence for India. Applied Economics Letters, 15(8), 607-616. 
[15]. Gopinath, G. (2004). Lending booms, sharp reversals and real exchange rate dynamics. Journal of International Economics, 62(1), 1-23.

[16]. Hausmann, R., \& Panizza, U. (2003). On the determinants of Original Sin: an empirical investigation. Journal of international Money and Finance, 22(7), 957-990.

[17]. https://dbie.rbi.org.in/DBIE/dbie.rbi?site=statistics\#!48

[18]. https://stats.bis.org/statx/srs/table/e1?p=20094\&c=\#

[19]. https://tradingeconomics.com/india/indicators

[20]. https://fred.stlouisfed.org/

[21]. https://rbi.org.in/Scripts/ECBView.aspx

[22]. https://www.finmin.nic.in/sites/default/files/SahooCom mittee_ecbReport_20150225.pdf

[23]. Kapoor, S. (2015). EXTERNAL COMMERCIAL BORROWINGS- AN ANALYSIS.

[24]. Kumarasamy, U. (2012). Does Foreign Exchange Reserve Affect External Commercial BorrowingsIndian Pragmatic Indication. Researchers World, 3(2 Part 2), 89.

[25]. Meisami, A., Misra, L., Mehran, J., \& Shi, Y. (2014). Foreign capital raising by Indian firms: An examination of domestic stock price response. Global Finance Journal, 25(3), 181-202.

[26]. Misra, P., \& Shettigar, J. (2020). Macroeconomic Variables Affecting External Commercial Borrowings: An Investigation. In Innovation, Technology, and Market Ecosystems (pp. 241-263): Springer.

[27]. Mohan, R., \& Kapur, M. (2009). Managing the impossible trinity: volatile capital flows and Indian monetary policy. Available at SSRN 1861724.

[28]. Mora, N., Neaime, S., \& Aintablian, S. (2013). Foreign currency borrowing by small firms in emerging markets: When domestic banks intermediate dollars. Journal of Banking \& Finance, 37(3), 1093-1107.

[29]. Narayan, S. (2008). Modifications of the External Commercial Borrowings Policy: Implications for Overseas Investments. ISAS Brief, 69.

[30]. Pacheco, M. (2012). Analyzing the Economics of External Commercial Borrowings in India.

[31]. Pal, P. (2016). Calm before the Storm? Economic \& Political Weekly, 51(12), 95.

[32]. Pandey, R., Pasricha, G. K., Patnaik, I., \& Shah, A. (2019). Motivations for capital controls and their effectiveness. International Journal of Finance \& Economics. doi:10.1002/ijfe.1795
[33]. Patnaik, I., Shah, A., \& Singh, N. (2014) Understanding foreign currency borrowing by firms: Evidence from India.

[34]. Patnaik, I., Shah, A., \& Singh, N. (2015). The Policy Puzzles of Foreign Currency Borrowing by Indian Firms. Paper presented at the India Policy Forum.

[35]. Pozo, S. (1992). Conditional exchange-rate volatility and the volume of international trade: evidence from the early 1900s. The review of Economics Statistics, 325-329.

[36]. Pradhan, \& Hiremath, G. S. (2019). External commercial borrowings by the corporate sector in India. Journal of Public Affairs, 20(1). doi:10.1002/pa.1987

[37]. Ray, P. (2017). India's External Commercial Borrowing: Trends, Composition, and Determinants. Indian Institute of Management Ranchi,

[38]. Sekhar, A. U. (2006). Funding corporate India: Opportunities in international financial markets. Economist Intelligence Unit briefing paper, 21-22.

[39]. Shukla, H. R. (2016). Sources of International Equity and Debt Fund for Indian Companies, Their Routes Capital Issues and Change in Regulations.

[40]. Singh, B. (2007). Corporate choice for overseas borrowings: The Indian evidence.

[41]. Singh, B. (2009). Changing contours of capital flows to India. Economic and Political Weekly, 58-66.

[42]. Sinha, P., \& Agnihotri, S. (2018). BAYESIAN AND EVT VALUE-AT-RISK ESTIMATES OF INDIA'S NON-FINANCIAL FIRMS

[43]. SRIVASTVA, A., \& RAMAN, S. N. (2017). AN OVERVIEW OF DIFFERENT SOURCES FORRAISING INTERNATIONAL FINANCE. International Journal of Business Management Insight \& Transformations [ISSN: 2581-4176 (online)], 1(1).

[44]. Sur, A., Ray, P., \& Nandy, A. (2019). India's external commercial borrowing: Pulled by domestic fundamentals or pushed by global conditions? Journal of Asian Economics, 61, 65-77.

[45]. Tripathy, S. N. (2019). Evaluating the Trends and Policies of External Commercial Borrowings (ECBs) in India. Orissa Economic Journal, 107.

[46]. Venkatesan, N. P. (2018). Macro and Micro Dimensions of External Commercial BorrowingsImplications for Indian Economy.

[47]. Verma, R., \& Prakash, A. (2011). Sensitivity of capital flows to interest rate differentials: An empirical assessment for India. Reserve Bank of India. 